\title{
Use of a vibrating mesh nebulizer for allergen challenge
}

Donald W. Cockcroft ${ }^{1 *}$, Beth E. Davis ${ }^{1}$, Christianne M. Blais ${ }^{1}$, Louis-Philippe Boulet ${ }^{2}$, Marie-Éve Boulay², Hélène Villeneuve ${ }^{2}$, Gail M. Gauvreau ${ }^{3}$, Paul M. O'Byrne ${ }^{3}$, Karen J. Howie ${ }^{3}$ and Caitlin D. Obminski ${ }^{3}$

\begin{abstract}
Background: Allergen inhalation tests are a valuable research tool. The allergen dose producing an early asthmatic response (EAR) can be predicted from methacholine responsiveness and allergen skin test endpoint (STE). The Wright ${ }^{\circledR}$ jet nebulizer, which is both inefficient and increasingly difficult to obtain, has been used historically. We assessed the Solo ${ }^{\circledR}$ vibrating mesh nebulizer as an alternative for allergen and methacholine challenges.

Methods: Eighteen mild atopic asthmatics completed the study. Doubling concentration allergen prick skin tests were performed to determine the STE in allergen units $/ \mathrm{mL}$. The Wright ${ }^{\circledR}$ protocol was used to measure the methacholine provocation dose causing a $20 \%$ forced expired volume in one second $\left(\mathrm{FEV}_{1}\right)$ fall $\left(\mathrm{PD}_{20}\right)(\mu \mathrm{g})$ and the allergen $\mathrm{PD}_{20}$ (units). The Solo ${ }^{\circledR}$ protocol $(0.5 \mathrm{~mL}$ nebulized to completion, tidal breathing inhalation) was used to determine both methacholine $\mathrm{PD}_{20}$ and allergen $\mathrm{PD}_{20}$. The nebulizer order was randomized and separated by $\geq 2$ weeks.
\end{abstract}

Results: All data were log transformed. The allergen $\mathrm{PD}_{20}$, predicted from the methacholine $\mathrm{PD}_{20}$ and the $\mathrm{STE}$, was within 2 doubling doses of the $\mathrm{PD}_{20}$ measured with the Wright ${ }^{\circledR}$ and 2.64 doubling doses of that measured with Solo ${ }^{\circledR}$. The Wright ${ }^{\circledR}$ allergen $\mathrm{PD}_{20}$ correlated with the Wright ${ }^{\circledR}$ methacholine $\mathrm{PD}_{20}(r=0.74)$ and the STE $(r=0.78)$ and more strongly with the product of the two (Wright ${ }^{\circledR}$ methacholine $\mathrm{PD}_{20} \times \mathrm{STE}, r=0.91, p<0.00001$ ). The Solo ${ }^{\circledR}$ allergen $\mathrm{PD}_{20}$ showed similar relationships with the Solo ${ }^{\circledR}$ methacholine $\mathrm{PD}_{20}(r=0.61)$, the $\mathrm{STE}(r=0.75)$ and the product of the two $\left(S_{0} o^{\circledR}\right.$ methacholine $\left.\mathrm{PD}_{20} \times \mathrm{STE}, \mathrm{r}=0.83, \mathrm{p}<0.00002\right)$. The Wright ${ }^{\circledR}$ and the Solo ${ }^{\circledR}$ methacholine geometric mean $\mathrm{PD}_{20} \mathrm{~S}$ were not significantly different (49.3 and $54.5 \mu \mathrm{g}$ respectively, $\left.\mathrm{p}=0.62\right)$. The Wright ${ }^{\circledR}$ allergen $\mathrm{PD}_{20}$ was slightly but significantly lower than the Solo ${ }^{\circledR}$ allergen $\mathrm{PD}_{20}$ (geometric means 6.7 and 10.5 units respectively, $\mathrm{P}=0.003$ ).

Conclusion: The Solo ${ }^{\circledR}$ allergen $\mathrm{PD}_{20}$ showed the same relationship with methacholine responsiveness and STE as did the Wright ${ }^{\circledR}$. The Solo ${ }^{\circledR}$ allergen $\mathrm{PD}_{20}$ was slightly but significantly higher than the Wright ${ }^{\circledR}$ allergen $\mathrm{PD}_{20}$. The Solo ${ }^{\circledR}$ vibrating mesh nebulizer was well tolerated and is an acceptable alternative for allergen challenge.

Trial registration clinicaltrials.gov: NCT03491358

Keywords: Allergen inhalation test, Methacholine inhalation test, Skin test endpoint, Jet nebulizer $\left(\right.$ Wright $\left.^{\circledR}\right)$, Vibrating mesh nebulizer $\left(\right.$ Solo $\left.^{\circledR}\right)$

\footnotetext{
*Correspondence: don.cockcroft@usask.ca

${ }^{1}$ Department of Medicine, University of Saskatchewan, Saskatoon, SK,

Canada

Full list of author information is available at the end of the article
} 


\section{Background}

Allergen inhalation challenge is a valuable research tool for the study of asthma pathophysiology and investigational new drug efficacy [1]. The early asthmatic response (EAR) to allergen depends on (non-allergic) airway responsiveness and the level of allergen-specific IgE [2]. It has been previously demonstrated that the concentration/dose of allergen required to produce a threshold EAR of a $20 \%$ decline in forced expired volume in one second $\left(\mathrm{FEV}_{1}\right)$ can be predicted within 2-3 concentrations using the level of airway responsiveness measured by methacholine or histamine provocation and the level of allergen specific IgE assessed by the allergen skin test endpoint titration (STE) [3]. A caveat for this prediction is the requirement for methacholine and allergen to be inhaled in the same fashion using the same type of nebulizer, calibrated to the same weight loss.

Historically, the Wright ${ }^{\circledR}$ jet nebulizer (Roxon MediTech, St. Leonard, QC) calibrated to run at a weight loss of $0.13 \mathrm{~g} / \mathrm{min}$ with inhalation performed by two minutes of tidal breathing [4] has been used for both methacholine and allergen inhalation. The Wright ${ }^{\circledR}$ nebulizer is inefficient (approximately $75 \%$ of weight loss is evaporation $[5,6])$, expensive, non-disposable, and increasingly difficult to acquire. The Aerogen Solo ${ }^{\circledR}$ vibrating mesh nebulizer, referred to as the Solo ${ }^{\circledR}$ throughout, (Aerogen Ltd, Galway Ireland) features no evaporation and has been validated for use in methacholine challenge testing $[7,8]$. The current study was designed to assess the Solo ${ }^{\circledR}$ vibrating mesh nebulizer for use in the standardized allergen challenge protocol performed in AllerGen National Centres of Excellence (NCE) Clinical Investigator Collaborative (CIC) studies and to compare it to the current Wright ${ }^{\circledR}$ jet nebulizer protocol.

\section{Methods}

\section{Participants}

Eligible participants had mild atopic asthma requiring only infrequent inhaled $\beta_{2}$ agonist, an $\mathrm{FEV}_{1}>70 \%$ predicted, and a methacholine provocation dose causing a $20 \%$ fall in $\mathrm{FEV}_{1}\left(\mathrm{PD}_{20}\right) \leq 400 \mu \mathrm{g}$. Participants were non-smokers with $<10$ pack year cumulative smoking history. Individuals who were pregnant, lactating, who had relevant allergen exposure or respiratory tract infection within the previous 4 weeks or who had significant medical conditions were excluded. Ethics approval was received from each study site and signed informed consent was obtained prior to study entry.

\section{Study design}

Participants attended the laboratory on 5 occasions. Visit 1 visit was to assess eligibility, to obtain signed consent, to perform baseline spirometry and screening allergen skin prick tests and from these select the best allergen for inhalation testing. The selected allergen was one which was clinically relevant to the participant and which produced a large $(\geq 5 \mathrm{~mm})$ wheal. The STE for the selected allergen was measured at Visit 2 to allow prediction of the starting allergen concentration for inhalation in conjunction with the methacholine response [3]. At Visits 2 and 3 the methacholine $\mathrm{PD}_{20}$ and the allergen $\mathrm{PD}_{20}$ were measured respectively both with either the Wright ${ }^{\circledR}$ or the Solo ${ }^{\circledR}$ nebulizer. After a minimum 2-week washout, at Visits 4 and 5 these challenges were repeated with the other nebulizer. The order of the nebulizers was randomized.

\section{Skin test endpoint (STE) titration}

The STE was determined as previously outlined [9]. Allergens (Omega Laboratories, Montreal QC) were dispensed in protein nitrogen units $/ \mathrm{mL}$, biologic allergen units $/ \mathrm{mL}$ or allergen units $/ \mathrm{mL}$. For conformity the allergen dose was expressed in "units". Allergens were diluted two-fold from $1: 8$ to $1: 1024$ or beyond if required and the dilutions were labeled as the allergen concentration in units $/ \mathrm{mL}$. Duplicate skin prick tests were performed, the mean wheal diameter measured at $10 \mathrm{~min}$, and the STE recorded as the weakest concentration (units $/ \mathrm{mL}$ ) causing a $2 \mathrm{~mm}$ mean wheal diameter.

\section{Methacholine inhalation tests}

The standard Wright ${ }^{\circledR}$ nebulizer methacholine test [4, 10] was done as follows. The nebulizer was calibrated to a weight loss of $0.13 \mathrm{~g} / \mathrm{min}$. Complete spirometry was initially measured in triplicate. Isotonic saline was then inhaled by tidal breathing for $2 \mathrm{~min}$, and the $\mathrm{FEV}_{1}$ (truncated manoeuvre to avoid fatigue) measured at 30 and $90 \mathrm{~s}$. Doubling concentrations of methacholine were then inhaled in the same manner at 5 min intervals with $\mathrm{FEV}_{1}$ repeated at 30 and $90 \mathrm{~s}$ The available concentrations ranged from 0.031 to $64 \mathrm{mg} / \mathrm{mL}$; the starting concentration for an individual was selected based on previous testing if available or based on validated guidelines $[10,11]$. Inhalations were stopped when the $\mathrm{FEV}_{1}$ had fallen $\geq 17 \%$ and the provocation concentration causing a $20 \% \mathrm{FEV}_{1}$ fall $\left(\mathrm{PC}_{20}\right)$ was interpolated from the last 2 data points [10] or extrapolated from the last data point [12]. The $\mathrm{PC}_{20}$ was converted to a $\mathrm{PD}_{20}(\mu \mathrm{g})$ based on several studies documenting that a Wright ${ }^{\circledR} \mathrm{PC}_{20}$ of $16 \mathrm{mg} / \mathrm{mL}$ equates to a $\mathrm{PD}_{20}$ of $400 \mu \mathrm{g}[6-8,13,14]$. The 
accepted values for a normal (negative) methacholine challenge test are $\mathrm{PC}_{20}$ and $\mathrm{PD}_{20}>16 \mathrm{mg} / \mathrm{mL}$ and $>400 \mu \mathrm{g}$ respectively [15].

The Solo ${ }^{\circledR}$ methacholine challenge was done as previously described [8]. Doubling doses of methacholine were delivered by nebulizing $0.5 \mathrm{~mL}$ of methacholine to completion and inhaling by tidal breathing; this requires 90 to $180 \mathrm{~s}$ [8]. A concentration of $2 \mathrm{mg} /$ $\mathrm{mL} \times 0.5 \mathrm{~mL} \times 0.4$ (respiratory duty cycle [16]) exposes the individual to $400 \mu \mathrm{g}$. Following saline inhalation appropriate doubling concentrations up to $4 \mathrm{mg} / \mathrm{mL}$ $(=800 \mu \mathrm{g})$ were used. The remainder of the challenge (timing of $\mathrm{FEV}_{1}$ measurements, time between doses, calculation of the $\mathrm{PD}_{20}$, etc.) was identical to the Wright ${ }^{\circledR}$ method.

\section{Allergen inhalation tests}

Allergen inhalation tests were done as previously described using the Wright ${ }^{\circledR}$ nebulizer [17]. Spirometry was measured in triplicate. Doubling concentrations of allergen were then inhaled ( 2 min of tidal breathing, nebulizer calibrated to a weight loss of $0.13 \mathrm{~g} / \mathrm{min}$ and starting 3 or 4 concentrations below the predicted EAR concentration [3]) at 12 min intervals until the $\mathrm{FEV}_{1}$ measured at $10 \mathrm{~min}$ after inhalation had fallen $\geq 15 \%$. At an $\mathrm{FEV}_{1}$ fall between 15 and $20 \%$ the $\mathrm{FEV}_{1}$ was repeated $10 \mathrm{~min}$ later before giving another concentration if required. The allergen $\mathrm{PC}_{20}$ (units $/ \mathrm{mL}$ ) was converted to allergen $\mathrm{PD}_{20}$ (units) assuming a similar relationship as seen with methacholine. After $\mathrm{PD}_{20}$ measurement, participants received a single inhaled dose of salbutamol $200 \mu \mathrm{g}$ to reverse bronchoconstriction and a single inhaled dose of fluticasone propionate $500 \mu \mathrm{g}$ to prevent development of the late asthmatic response [18].

The Solo ${ }^{\circledR}$ allergen challenge was performed in an analogous manner. Assuming a similar relationship for dose comparison between the Solo ${ }^{\circledR}$ and the Wright ${ }^{\circledR}$ nebulizers seen with methacholine, the starting allergen concentration was 3 doubling concentrations below the starting concentration used for the Wright ${ }^{\circledR}$ (i.e. 6-7 concentrations below the Wright ${ }^{\circledR}$ prediction). The allergen, $0.5 \mathrm{~mL}$, was nebulized to completion and inhaled by tidal breathing; the remainder of the challenge protocol was identical to the Wright ${ }^{\circledR}$ protocol; the result was expressed as the allergen $\mathrm{PD}_{20}$ in units.

\section{Analysis}

Statistics were done using a computerized statistics programme (Statistix 9 (Analytical Software, Tallahassee, FL, USA). $\mathrm{PD}_{20}$ and STE values were log transformed prior to analysis. The Student's paired t test was used for comparison of means. Linear regression analysis was used for the following (all values logged):
Measured Wright ${ }^{\circledR}$ allergen $\mathrm{PD}_{20}$ vs Predicted allergen $\mathrm{PD}_{20}$.

Wright ${ }^{\circledR}$ allergen $\mathrm{PD}_{20}$ vs Wright $^{\circledR}$ methacholine $\mathrm{PD}_{20}$.

Wright ${ }^{\circledR}$ allergen $\mathrm{PD}_{20}$ vs STE.

Wright $^{\circledR}$ allergen $\mathrm{PD}_{20}$ vs (Wright ${ }^{\circledR}$ methacholine $\left.\mathrm{PD}_{20} \times \mathrm{STE}\right)$.

Measured Solo ${ }^{\circledR}$ allergen $\mathrm{PD}_{20}$ vs Predicted allergen $\mathrm{PD}_{20}$.

Solo ${ }^{\circledR}$ allergen $\mathrm{PD}_{20}$ vs Solo ${ }^{\circledR}$ methacholine $\mathrm{PD}_{20}$.

Solo ${ }^{\circledR}$ allergen $\mathrm{PD}_{20}$ vs STE.

Solo ${ }^{\circledR}$ allergen $\quad \mathrm{PD}_{20}$ vs $\quad\left(\mathrm{Solo}^{\circledR}\right.$ methacholine $\left.\mathrm{PD}_{20} \times \mathrm{STE}\right)$.

\section{Results}

Eighteen participants, all poylsensitized but with no current allergen exposure (except house dust mite), completed the study without adverse events. Three additional enrolled participants did not complete the study; one because the $\mathrm{FEV}_{1}$ was $<70 \%$ at Visit 1 , one because the methacholine $\mathrm{PD}_{20}$ was $>400 \mu \mathrm{g}$ at Visit 2, and one because of a failure to respond to allergen (1:32 with the Solo ${ }^{\circledR}$ equating to $\sim 1: 4$ with the Wright $^{\circledR}$ ) at Visit 3. Anthropometric data, baseline $\mathrm{FEV}_{1}$, baseline methacholine $\mathrm{PD}_{20}$ and allergen used for challenges are shown in Table 1.

\section{Wright $^{\circledR}$}

The measured allergen $\mathrm{PD}_{20}$ correlated with the predicted allergen $\mathrm{PD}_{20}(\mathrm{r}=0.91, \mathrm{p}<0.00001)$ and all predictions were within 2 (maximum 1.96) doubling doses of the measured allergen $\mathrm{PD}_{20}$ (Fig. 1). The geometric means for the measured and predicted $\mathrm{PD}_{20}$ values were 6.7 units (95\% CI 2.7-15.8) and 7.0 units (95\% CI 2.517.7) respectively $(\mathrm{p}=0.68)$. The allergen $\mathrm{PD}_{20}$ (units) correlated with both the methacholine $\mathrm{PD}_{20}(\mathrm{r}=0.74)$ and the STE $(r=0.78$,$) . Allergen \mathrm{PD}_{20}$ correlated more strongly with the product of the methacholine $\mathrm{PD}_{20}(\mu \mathrm{g})$ and the STE (units $/ \mathrm{mL})(\mathrm{r}=0.91, \mathrm{p}<0.00001)$ (Fig. 2).

\section{Solo ${ }^{\circledR}$}

The measured Solo ${ }^{\circledR}$ allergen $\mathrm{PD}_{20}$ correlated with the predicted allergen $\mathrm{PD}_{20}(\mathrm{r}=0.84, \mathrm{p}=0.000013)$ and was within 2 doubling does of the predicted allergen $\mathrm{PD}_{20}$ in 14 of 18 and within 2.64 doubling doses in all 18 (Fig. 3). Similar to the Wright ${ }^{\circledR}$, the Solo ${ }^{\circledR}$ allergen $\mathrm{PD}_{20}$ correlated with both the Solo ${ }^{\circledR}$ methacholine $\operatorname{PD}_{20}(r=0.61)$ and the STE $(r=0.75)$ and more strongly with the product of the $2(\mathrm{r}=0.83, \mathrm{p}=0.00002)$ (Fig. 4). 
Table 1 Demographics, $\mathrm{FEV}_{1}$, methacholine $\mathrm{PD}_{20}$, and allergen used for inhalation

\begin{tabular}{|c|c|c|c|c|c|c|c|c|c|}
\hline Participant & Site $^{a}$ & Sex & Age (year) & Height $(\mathrm{cm})$ & Weight (kg) & $\mathrm{FEV}_{1}(\mathrm{~L})$ & FEV $_{1}(\%)$ & $\begin{array}{l}\text { Methacholine } \\
\text { PD20 }(\mu \mathrm{g})\end{array}$ & Allergen \\
\hline 1 & S & $M$ & 42 & 178 & 86.4 & 3.50 & 84 & 29.1 & Cat \\
\hline 2 & S & M & 24 & 170 & 81.8 & 4.15 & 98 & 82.7 & Cat \\
\hline 3 & S & $\mathrm{F}$ & 25 & 170 & 70.9 & 3.53 & 98 & 55.4 & Cat \\
\hline 4 & S & M & 27 & 170 & 79.5 & 3.60 & 87 & 81.5 & Cat \\
\hline 5 & S & $\mathrm{F}$ & 23 & 162 & 48.6 & 2.68 & 82 & 118 & Mite \\
\hline 6 & S & F & 42 & 158 & 54.5 & 2.49 & 90 & 10.5 & Mite \\
\hline 7 & L & M & 42 & 173 & 67.9 & 3.44 & 88 & 171 & Birch \\
\hline 8 & L & $\mathrm{F}$ & 30 & 162 & 66.9 & 3.66 & 115 & 239 & Cat \\
\hline 9 & L & M & 35 & 182 & 63.1 & 3.78 & 82 & 142 & Cat \\
\hline 10 & L & $\mathrm{F}$ & 38 & 157 & 77.6 & 2.61 & 92 & 8.9 & Cat \\
\hline 11 & L & $\mathrm{F}$ & 25 & 152 & 83.0 & 3.16 & 112 & 1.9 & Cat \\
\hline 12 & L & M & 34 & 186 & 73.2 & 3.66 & 88 & 26.6 & Horse \\
\hline 13 & M & M & 58 & 184 & 102.0 & 3.69 & 92 & 162 & Mite \\
\hline 14 & M & M & 54 & 175 & 76.0 & 3.40 & 95 & 80.6 & Cat \\
\hline 15 & M & M & 28 & 181 & 87.9 & 4.57 & 98 & 18.1 & Grass \\
\hline 16 & M & $F$ & 21 & 174 & 72.5 & 3.08 & 82 & 46.5 & Grass \\
\hline 17 & M & F & 25 & 161 & 69.5 & 2.50 & 78 & 265 & Ragweed \\
\hline 18 & M & F & 30 & 167 & 80.0 & 3.36 & 101 & 29.4 & Mite \\
\hline Mean & & & 33.5 & 170.1 & 74.5 & 3.38 & 92.3 & $49.3^{b}$ & \\
\hline SD & & & 10.7 & 10.0 & 12.4 & 0.55 & 10.1 & $(25.8-94.0)$ & \\
\hline
\end{tabular}

a Site: $\mathrm{S}=$ Saskatchewan, $\mathrm{L}=$ Laval, $\mathrm{M}=$ McMaster

b Geometric mean (95\% confidence intervals)

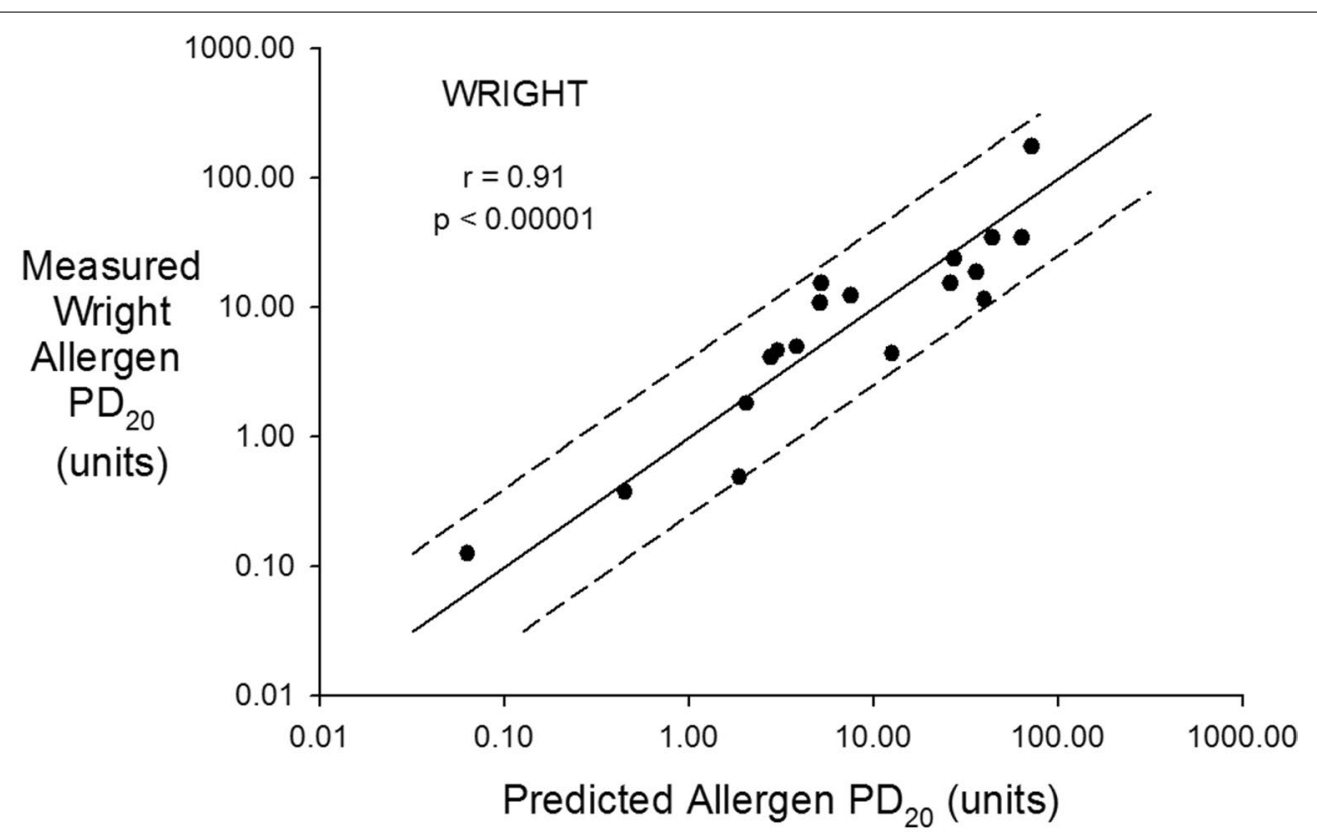

Fig. 1 Measured Wright ${ }^{\circledR}$ allergen $\mathrm{PD}_{20}$ (units) on the vertical axis and predicted allergen $\mathrm{PD}_{20}$ (units) on the horizontal axis both plotted in a log scale. The solid line is the line of identity and the dashed lines represent \pm 2 doubling doses 


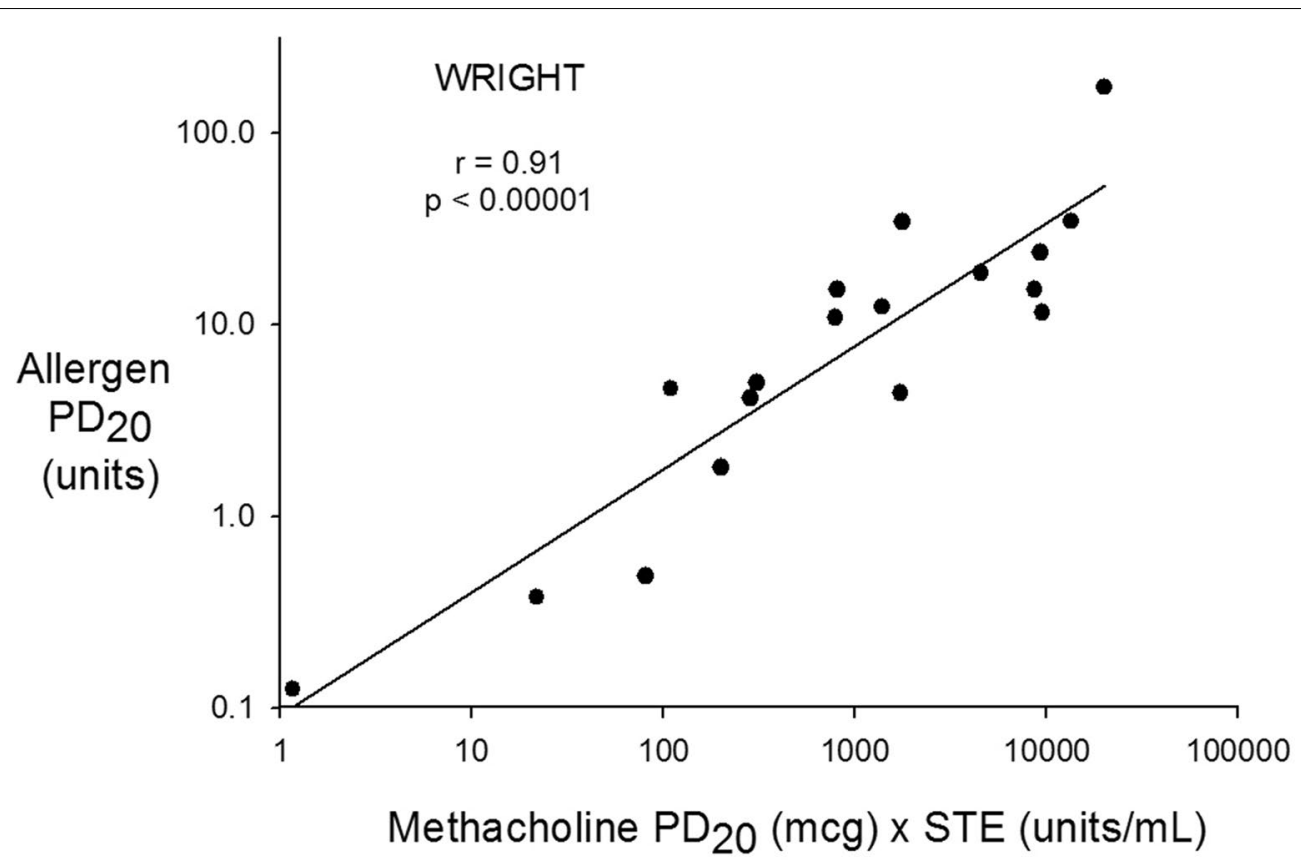

Fig. 2 Wright ${ }^{\circledR}$ allergen $\mathrm{PD}_{20}$ on the vertical axis and Wright ${ }^{\circledR}$ Methacholine $\mathrm{PD}_{20} \times \mathrm{STE}$ on the horizontal axis both plotted on a log scale. The regression equation is; Log Allergen $\mathrm{PD}_{20}$ (units) $=-1.03+0.64 \times \log$ (Methacholine $\mathrm{PD}_{20}[\mu \mathrm{g}] \times \mathrm{STE}[\mathrm{units} / \mathrm{mL}]$ )



Fig. 3 Measured Solo ${ }^{\circledR}$ allergen $\mathrm{PD}_{20}$ (units) on the vertical axis and predicted allergen $\mathrm{PD}_{20}$ (units) on the horizontal axis both plotted in a log scale. The solid line is the line of identity, the dashed lines represent \pm 2 doubling doses and the dotted lines \pm 2.64 doubling doses

\section{Wright ${ }^{\circledR}$ Solo $^{\circledR}$ comparisons}

The Wright ${ }^{\circledR}$ and the Solo ${ }^{\circledR}$ methacholine $\mathrm{PD}_{20} \mathrm{~s}$ were not significantly different with geometric means of 49.3 (95\% CI 25.8-94.0) and 54.2 $\mu \mathrm{g}$ (95\% CI 26.7-110) respectively $(\mathrm{p}=0.62)$. The geometric mean Wright ${ }^{\circledR}$ allergen $\mathrm{PD}_{20}, 6.7$ units (95\% CI 2.7-15.8), was slightly but significantly lower than geometric mean Solo ${ }^{\circledR}$ allergen $\mathrm{PD}_{20}, 10.5$ units $(95 \%$ CI 4.4-25.1), $(\mathrm{p}=0.003)$. Individual values for the $\mathrm{Wright}^{\circledR}$ 


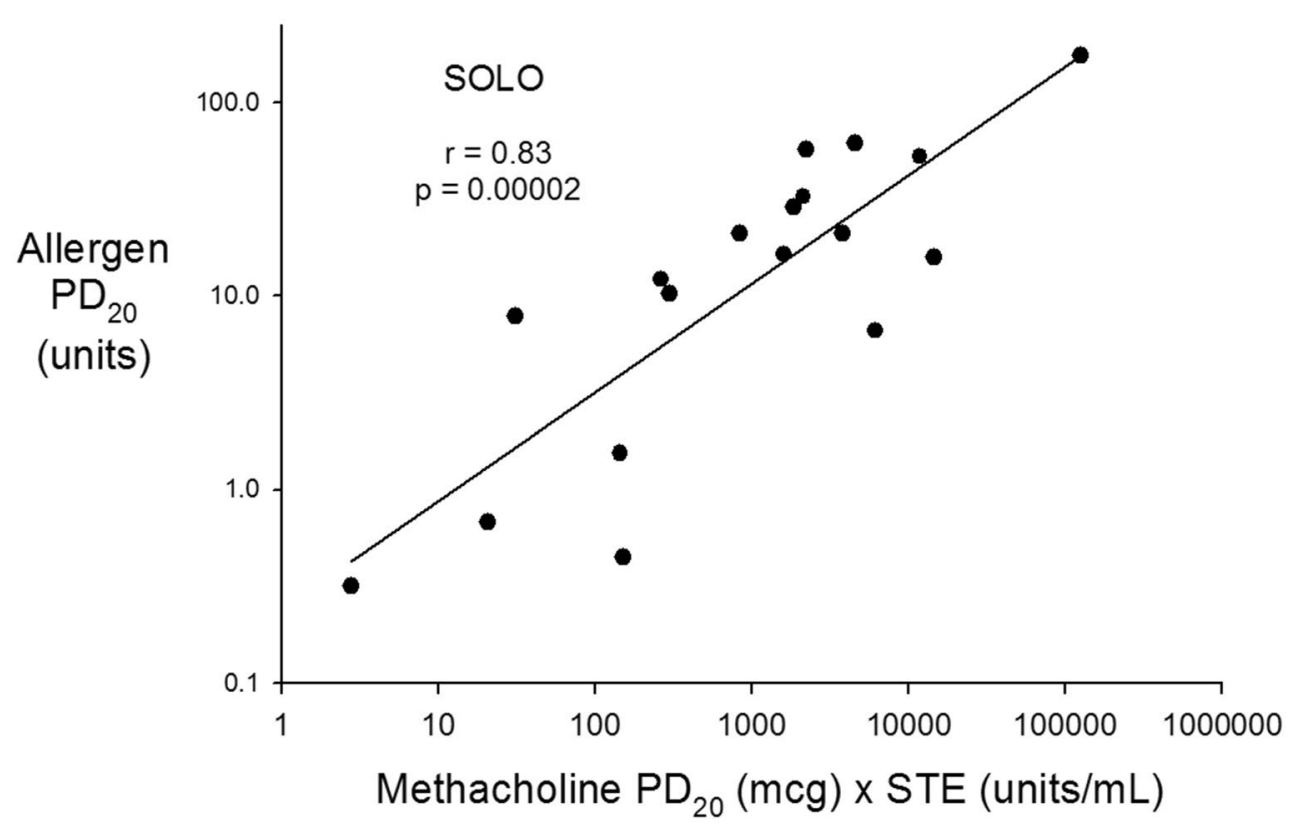

Fig. 4 Solo ${ }^{\circledR}$ allergen $\mathrm{PD}_{20}$ on the vertical axis and Solo ${ }^{\circledR}$ Methacholine $\mathrm{PD}_{20} \times \mathrm{STE}$ on the horizontal axis plotted on a log scale. The regression equation is; Log Allergen $\mathrm{PD}_{20}$ (units) $=-0.62+0.56 \times \log$ (Methacholine $\mathrm{PD}_{20}[\mu \mathrm{g}] \times \mathrm{STE}$ [units $\left./ \mathrm{mL}\right]$ )

and the Solo ${ }^{\circledR}$ allergen $\mathrm{PD}_{20}$ s are shown in Fig. 5. There was no sequence effect (i.e. nebulizer order) nor was there any difference between the three sites.

\section{Discussion}

These data indicate that the Solo ${ }^{\circledR}$ vibrating mesh nebulizer can be successfully used for performance of allergen inhalation tests. Allergen responsiveness showed the same relationship with methacholine responsiveness and level of allergen sensitivity as was seen with the Wright ${ }^{\circledR}$ nebulizer protocol. The measured Solo ${ }^{\circledR}$ allergen $\mathrm{PD}_{20}$ was within 2.64 doubling doses of the prediction.

In 1987, an equation was developed to predict the dilution/concentration of allergen that would produce a 20\% EAR [3]. This was based on the histamine $\mathrm{PC}_{20}$ $(\mathrm{mg} / \mathrm{mL})$ and the allergen skin test endpoint (dilution) producing a $2 \mathrm{~mm}$ wheal. Both allergen and histamine were inhaled with 2 min of tidal breathing from a Wright ${ }^{\circledR}$ nebulizer calibrated in the same manner. Methacholine was subsequently substituted for histamine in the same concentration since histamine and methacholine $\mathrm{PC}_{20} \mathrm{~S}$ are identical in asthmatics [19]. In the original study, the equation successfully estimated the dilution required for an EAR within 2 doubling dilutions in $92 \%$ and 3 doubling dilutions in $100 \%$ of challenges [3]. The equation and a sample calculation are below:

Log predicted allergen dilution

$$
=0.68 \log \left(\text { methacholine } \mathrm{PC}_{20} \times \mathrm{STE} \text { dilution }\right)
$$

For example with a methacholine $\mathrm{PC}_{20}$ of $2.2 \mathrm{mg} / \mathrm{mL}$ and an STE of 1/1024.

Log predicted allergen dilution

$$
=0.68 \log (2.2 \times 1 / 1024)=-1.81
$$

Predicted allergen dilution $=\operatorname{antilog}(-1.81)$

$$
=0.0155 \sim 1 / 64 \text { dilution. }
$$

This prediction is routinely used as a guide for allergen challenge tests. A starting allergen dilution of 3 or occasionally 4 doubling dilutions below the prediction has proved a safe and effective method for allergen challenges performed in AllerGen NCE CIC and other studies. The purpose is to allow some test shortening when compared to methods advocating starting with the weakest allergen dilution causing a $2 \mathrm{~mm}$ wheal skin test response [20]. The current study validates this prediction equation when applied to the Wright ${ }^{\circledR}$ data, since all measured values were within 2 doubling doses of the prediction. Despite the slightly higher measured Solo ${ }^{\circledR}$ allergen $\mathrm{PD}_{20}$ vs the Wright ${ }^{\circledR}$ (i.e. slightly less responsive), 78\% of values were within 2 doubling doses and $100 \%$ within 2.64 doubling doses. This would suggest that the 1987 prediction equation can be safely and effectively used (with modification for the units and nebulizer differences) until such time as there are enough data to develop a "Solo ${ }^{\circledR}$ specific" equation. 


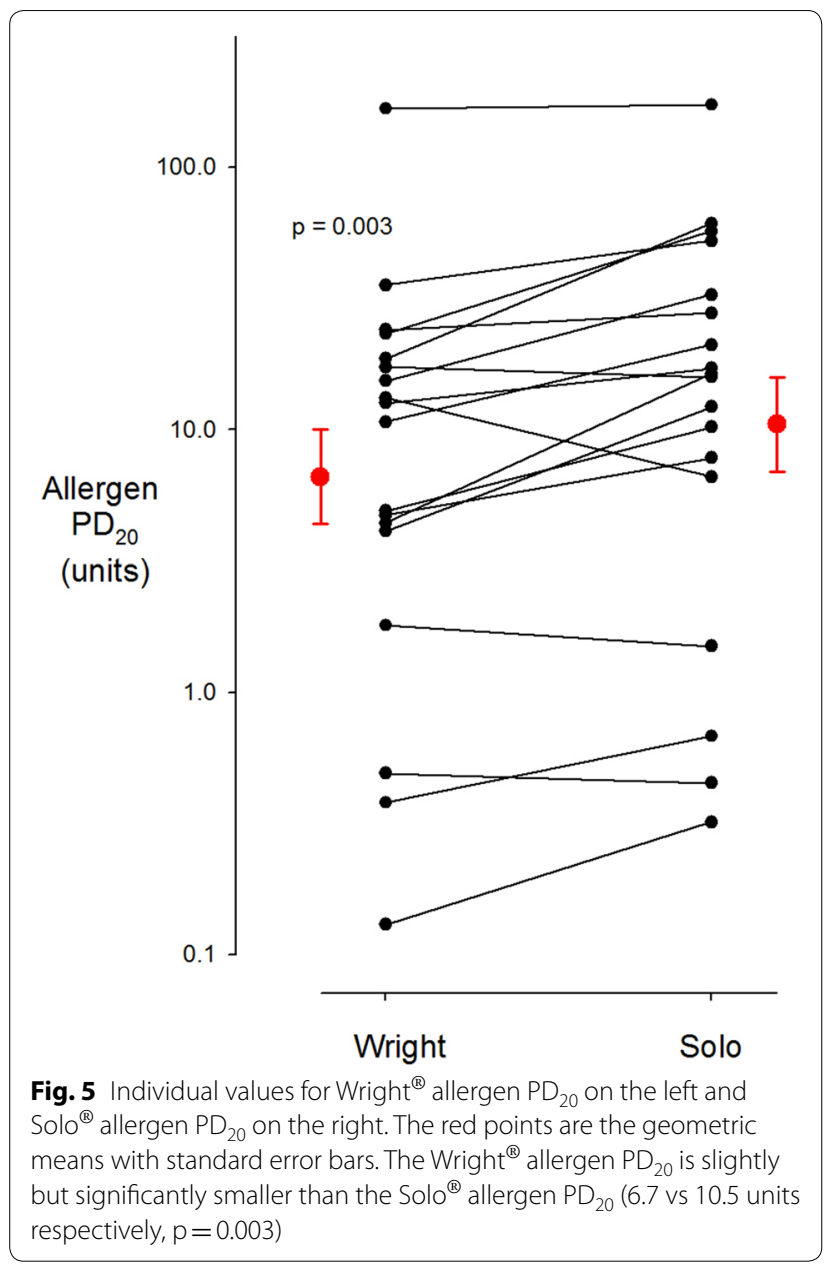

The major strength of this study is the experienced group of investigators at the three sites. The one weakness is the inability to assess the solute output of the jet (Wright ${ }^{\circledR}$ ) nebulizer. Based on the known evaporative features [5, 6], and both breath simulation testing [6] and clinical challenge testing $[7,8,12,13]$ it is reasonable to equate a methacholine $\mathrm{PC}_{20}$ of $16 \mathrm{mg} / \mathrm{mL}$ to a methacholine $\mathrm{PD}_{20}$ of $400 \mu \mathrm{g}$. The current study validates this, since using this conversion the Wright ${ }^{\circledR}$ and Solo ${ }^{\circledR}$ methacholine $\mathrm{PD}_{20} \mathrm{~S}$ were essentially identical. However, data are currently lacking for nebulized allergen and it is possible that allergen solutions could be handled differently by the nebulizers.

\section{Conclusion}

In summary the Solo ${ }^{\circledR}$ vibrating mesh nebulizer, proved to be a safe, effective and well tolerated device for administering inhaled allergen. This provides a valuable alternative to the Wright ${ }^{\circledR}$ jet nebulizer.

\section{Abbreviations}

STE: skin (prick) test endpoint; $\mathrm{FEV}_{1}$ : forced expired volume in one second; $\mathrm{PC}_{20}$ : provocation concentration causing a $20 \% \mathrm{FEV}_{1}$ fall; $\mathrm{PD}_{20}$ : provocation dose causing a 20\% FEV fall; EAR: early asthmatic response; SD: standard deviation; Cl: confidence interval; NCE: National Centres of Excellence; CIC: Clinical Investigator Collaborative.

\section{Acknowledgements}

The authors thank Jacquie Bramley for assistance in preparation of the manuscript and Aerogen Ltd for supplying the Solo ${ }^{\circledR}$ nebulizers.

\section{Authors' contributions}

Study design and protocol development: BED, CMB, DWC, GMG, PMO, LPB: Data collection: BED, CMB, DWC, LPB, MEB, GMG, HV, KJH, CDO; data analysis: DWC, CMB, BED; Manuscript preparation: DWC, BED, CMB; manuscript approval. All authors read and approved the final manuscript.

\section{Funding}

This study was funded by a grant form AllerGen NCE. AllerGen had no role in study design, data collection analysis or interpretation, or in the writing of the manuscript. CMB received a summer student support grant from the CSACI

\section{Availability of data and materials}

All data are available from the corresponding author on reasonable request don.cockcroft@usask.ca.

\section{Ethics approval and consent to participate}

Ethics approval was obtained from each site and signed informed consent was obtained from each participant.

\section{Consent for publication}

We consent to publication of this paper.

\section{Competing interests}

The authors declare that they have no competing interests.

\section{Author details}

${ }^{1}$ Department of Medicine, University of Saskatchewan, Saskatoon, SK, Canada. ${ }^{2}$ Institut Universitaire de Cardiologie et de Pneumologie de Québec, Université Laval, Québec City, QC, Canada. ${ }^{3}$ Department of Medicine, McMaster University, Hamilton, ON, Canada.

Received: 12 October 2019 Accepted: 14 November 2019

Published online: 26 November 2019

\section{References}

1. Boulet LP, Gauvreau G, Boulay ME, O'Byrne P, Cockcroft DW, Clinical Investigative Collaboration, Canadian Network of Centers of Excellence AllerGen. The allergen bronchoprovocation model: an important tool for the investigation of new asthma anti-inflammatory therapies. Allergy. 2007;62(10):1101-10

2. Cockcroft DW, Ruffin RE, Frith PA, Cartier A, Juniper EF, Dolovich J, et al. Determinants of allergen-induced asthma: dose of allergen, circulating IgE antibody concentration, and bronchial responsiveness to histamine. Am Rev Respir Dis. 1979;120(5):1053-8.

3. Cockcroft DW, Murdock KY, Kirby J, Hargreave FE. Prediction of airway responsiveness to allergen from skin sensitivity to allergen and airway responsiveness to histamine. Am Rev Respir Dis. 1987;135(1):264-7.

4. Cockcroft DW, Killian DN, Mellon JJA, Hargreave FE. Bronchial reactivity to inhaled histamine: a method and clinical survey. Clin Allergy. 1977;7(3):235-43.

5. Cockcroft DW, Hurst TS, Gore BP. Importance of evaporative water losses during standardized nebulized inhalation provocation tests. Chest. 1989;96(3):505-8.

6. Coates AL, Leung K, Dell SD. Developing alternative delivery systems for methacholine challenge tests. J Aerosol Med Pulm Drug Deliv. 2014;27(1):66-70.

7. Blais CM, Cockcroft DW, Veilleux J, Boulay ME, Boulet LP, Gauvreau GM, et al. Methacholine challenge: comparison of airway responsiveness 
produced by a vibrating mesh nebulizer versus a jet nebulizer. J Aerosol Med Pulm Drug Deliv. 2018;31(2):88-93.

8. Davis BE, Simonson SK, Blais CM, Cockcroft DW. Methacholine challenge testing: a novel method for measuring $\mathrm{PD}_{20}$. Chest. 2017;152(6):1251-7.

9. Blais CM, Davis BE, Cockcroft DW. Within-tester repeatability and between-tester reproducibility of skin test endpoint titration: a quality assurance study. Ann Allergy Asthma Immunol. 2019:122(2):220-2.

10. Juniper EF, Cockcroft DW, Hargreave FE. Histamine and methacholine inhalation tests: tidal breathing method-laboratory procedure and standardisation. 2nd ed. Sweden: AB Draco, Lund; 1994.

11. Cockcroft DW, Marciniuk DD, Hurst TS, Cotton DJ, Laframboise KF, McNab $\mathrm{BD}$, et al. Methacholine challenge: test-shortening procedures. Chest. 2001;120(6):1857-60.

12. Cockcroft DW, Davis BE. Methacholine PC20: 1-point formula. Ann Allergy Asthma Immunol. 2007;98(5):498-9.

13. Dell SD, Bola SS, Foty RG, Marshall LC, Nelligan KA, Coates AL. Provocative dose of methacholine causing a 20\% drop in $\mathrm{FEV}_{1}$ should be used to interpret methacholine challenge tests with modern nebulizers. Ann Am Thorac Soc. 2015;12(3):357-63.

14. El-Gammal Al, Killian KJ, Scime TX, Beaudin S, Schlatman A, Cockcroft DW, et al. Comparison of the provocative concentration of methacholine causing a 20\% fall in FEV 1 between the AeroEclipse II breath-actuated nebulizer and the wright nebulizer in adult subjects with asthma. Ann Am Thorac Soc. 2015;12(7):1039-43.

15. Coates AL, Wanger J, Cockcroft DW, Culver BH, Bronchoprovocation Testing Task Force. ERS technical standard on bronchial challenge testing: general considerations and performance of methacholine challenge tests. Eur Respir J. 2017;49(5):1601526. https://doi.org/10.1183/13993 003.01526-2016.
16. Blais CM, Davis BE, Graham BL, Cockcroft DW. Respiratory duty cycles in individuals with and without airway hyperresponsiveness. Chest. 2019. https://doi.org/10.1016/..chest.2019.09.005.

17. Davis BE, Todd DC, Cockcroft DW. Effect of combined montelukast and desloratadine on the early asthmatic response to inhaled allergen. J Allergy Clin Immunol. 2005;116(4):768-72.

18. Cockcroft DW, McParland CP, O'Byrne PM, Manning P, Friend JL, Rutherford BC, et al. Beclomethasone given after the early asthmatic response inhibits the late response and the increased methacholine responsiveness and cromolyn does not. J Allergy Clin Immunol. 1993;91(6):1163-8.

19. Juniper EF, Frith PA, Dunnett C, Cockcroft DW, Hargreave FE. Reproducibility and comparison of responses to inhaled histamine and methacholine. Thorax. 1978:33:705-10.

20. Killian D, Cockcroft DW, Hargreave FE, Dolovich J. Factors in allergeninduced asthma: relevance of the intensity of the airways allergic reaction and non-specific bronchial reactivity. Clin Allergy. 1976;6(3):219-25.

\section{Publisher's Note}

Springer Nature remains neutral with regard to jurisdictional claims in published maps and institutional affiliations.
Ready to submit your research? Choose BMC and benefit from:

- fast, convenient online submission

- thorough peer review by experienced researchers in your field

- rapid publication on acceptance

- support for research data, including large and complex data types

- gold Open Access which fosters wider collaboration and increased citations

- maximum visibility for your research: over 100M website views per year

At BMC, research is always in progress.

Learn more biomedcentral.com/submissions 